\title{
Developing a Framework of the Sourcing Process-A Case Study of Finnish Companies With Chinese Suppliers*
}

\author{
Lingyun Wang, Matti Muhos \\ University of Oulu, Oulu, Finland \\ Maaria Pennanen \\ Vacon Plc., Vaasa, Finland \\ Pekka Kess \\ University of Oulu, Oulu, Finland
}

\begin{abstract}
The paper analyzes five Finnish case companies to study the sourcing process from China. A framework of a six-stage sourcing process is developed that includes finding and choosing suppliers, making contracts and orders, performing production and quality control, planning logistics, inspecting purchases, and developing supply chain management. Each stage describes the activities from the channels of seeking suppliers to cooperative areas for further development. The case study illustrates the practices of sourcing from China are actually quite similar to the sourcing process in other countries. The study highlights that quality control is the core issue in sourcing from China. Moreover, the difference in understanding sustainable quality affects supplier screening and quality control. Close cooperation on quality control is the key to managing the supply chain to increase competitive advantage through sourcing from China.
\end{abstract}

Keywords: sourcing process, Chinese supplier, case study

\section{Introduction}

Managing purchasing in the supply chain has been a challenge in the last decade for many corporations (Karpak, Kumcu \& Kasuganti, 2001). Supply chain management is not just a domestic phenomenon. The supply chain transcends national boundaries, imposing the challenges of globalization on managers who design supply chains for existing and new product lines (Meixell \& Gargeya, 2005). The catalyst for global sourcing has been worldwide competitive pressure forcing firms to reduce costs and to improve quality and responsiveness (Gelderman \& Semeijn, 2006). Global supply chains are more difficult to manage than domestic supply chains. Substantial geographical distances in these global situations not only increase transportation

\footnotetext{
* The authors are grateful for project funding support from the Finnish Centre for Economic Development, Transport and the Environment (ELY-Keskus) and the European Regional Development Fund. We highly appreciate the companies involved in the study sharing their experiences. We also thank the two blind reviewers for their comments that helped develop the paper.

Lingyun Wang, Ph.D., Department of Industrial Engineering and Management, University of Oulu.

Matti Muhos, Dr. Eng., Research Director, Oulu Southern Institute, University of Oulu.

Maaria Pennanen, M.Sc. Eng., M.Sc. Econ., Research and Development, Vacon Plc.

Pekka Kess, Dr. Sc., Dr. Eng., Department of Industrial Engineering and Management, University of Oulu.

Correspondence concerning this article should be addressed to Lingyun Wang, University of Oulu, P.O. Box 4610, FI-90014

University of Oulu, Finland. E-mail: lingyunw@yahoo.com.
} 
costs but also complicate decisions because of inventory cost trade-offs due to increased lead-time in the supply chain (Pennanen, Muhos, Wang, \& Kess, 2011).

Interest in China has soared in recent years because of the booming economy (Pyke, Robb, \& Farley, 2000). Due to China's economic growth and increasing global competition, China is gradually becoming an attractive sourcing destination rather than merely a market for many foreign companies (Campbell, Hexter, \& Yin, 2004), especially in the case of manufactured products and components (Enderwick, 2009). Moving sourcing to China is a challenge for foreign companies because of various difficulties, such as intellectual property infringements, customs delay, poor communication between headquarters and suppliers (Campbell, Hexter, \& Yin, 2004), quality fade (Enderwick 2009), unpredictable inflation rates, problems of government intervention (Mentzer, 2001), and long geographic distance and increased delivery time (Fredriksson \& Jonsson, 2009). Although low cost is the main motivation for sourcing from China (Salmi, 2006), the degree of cost advantage is also a concern (e.g., Salmi, 2006) when decreased delivery precision may increase costs in terms of expedited freight, unfulfilled demands, extra inventory, and managerial time spent on “fire-fighting” (Fredriksson \& Jonsson, 2009).

Although many hurdles exist in sourcing from China, well-organized procurement practices are a source of competitive advantage when foreign companies have strong ties to suppliers in China and adopt best practices that cut operating costs and improve lead-time (Campbell et al., 2004). Therefore, mapping a good sourcing process is an important concern for foreign companies when moving sourcing to China. The question of "how to start and operate" is usually proposed by many practitioners taking advantage of cost competitiveness.

Zhang and Goffin (2001) summarized that supply management research focused on supplier selection and evaluation, sourcing strategy, developing relationships with suppliers, contextual issues influencing supplier management, and supplier management in Chinese international joint ventures (IJVs). Zeng's (2003) study shows that the studies on sourcing process design and management are very limited. This paper focuses on the sourcing process of supply chain management (SCM) with Chinese suppliers. The research questions are how to develop sourcing activities with Chinese suppliers and what the sourcing process from China is. The scope of the study ranges from the channels of finding suppliers to the interactions in the sourcing process. The objective of the research is to develop a framework for the sourcing process based on the experience of Finnish case companies with Chinese suppliers. The purpose of the study is to facilitate the sourcing process of supply chain management.

The rest of the paper is organized as follows. The literature review presents some studies on the sourcing process. The research design section introduces the selection of research methodology and the data collection and analysis. Then, cross-case analysis is discussed after the empirical study describes the practices of five Finnish case companies sourcing from China. The final part consists of the concluding remarks, research limitations, and further study.

\section{Literature Review}

SCM is the integration of key business processes from end-users through original suppliers providing products, services, and information and adding value for customers and other stakeholders (Min \& Zhou 2002; Cooper, Lambert, \& Pagh, 1997). SCM is the process of managing relationships, information, and materials flow across enterprise borders to deliver enhanced customer service and economic value through synchronized management of the flow of physical goods and associated information from sourcing to consumption (Mentzer, 
2001). Purchasing is one of the strategic functions with the highest potential impact on a firm's long-term profitability (Quintens, Pauwels, \& Matthyssens, 2006). Van Weele (2005) defined purchasing as:

the management of the company's external resources in such a way that the supply of all goods, services, capabilities and knowledge which are necessary for running, maintaining and managing the company's primary and support activities is secured at the most favorable conditions. (p. 8)

The scope of purchasing has increased from buying operations to supply management (Salmi, 2006).

Referring to Van Weele (2005), procurement, purchasing, sourcing, and supply management can be used interchangeably. Therefore, the terms are homogenous in this paper.

Quintens, Pauwels, and Matthyssens (2006) conceptualized the purchasing process, and defined four phases: (1) the investigation of purchase markets and the screening of potential suppliers; (2) the selection of supplies; (3) the negotiation and contraction; and (4) supplier evaluation and follow-up. Coordinating purchasing encompasses creating purchasing synergies from economies of scale, scope, process, and learning.

Van Weele (2005) illustrated the main activities within the purchasing function and the purchasing process model (see Figure 1). These activities aim at (Van Weele, 2005):

- Determining the purchasing goods and services specifications in terms of required quality and quantities;

- Selecting the best potential suppliers and developing mechanisms to be able to do this;

- Preparing and conducting negotiations with the supplier in order to achieve an agreement and legal contract;

- Placing the order with the selected supplier or to develop efficient purchase order and handling routines;

- Monitoring and controlling the order to secure delivery;

- Following up and evaluating the elements setting claims, keeping product and supplier files up-to-date, supplier rating, and supplier ranking.

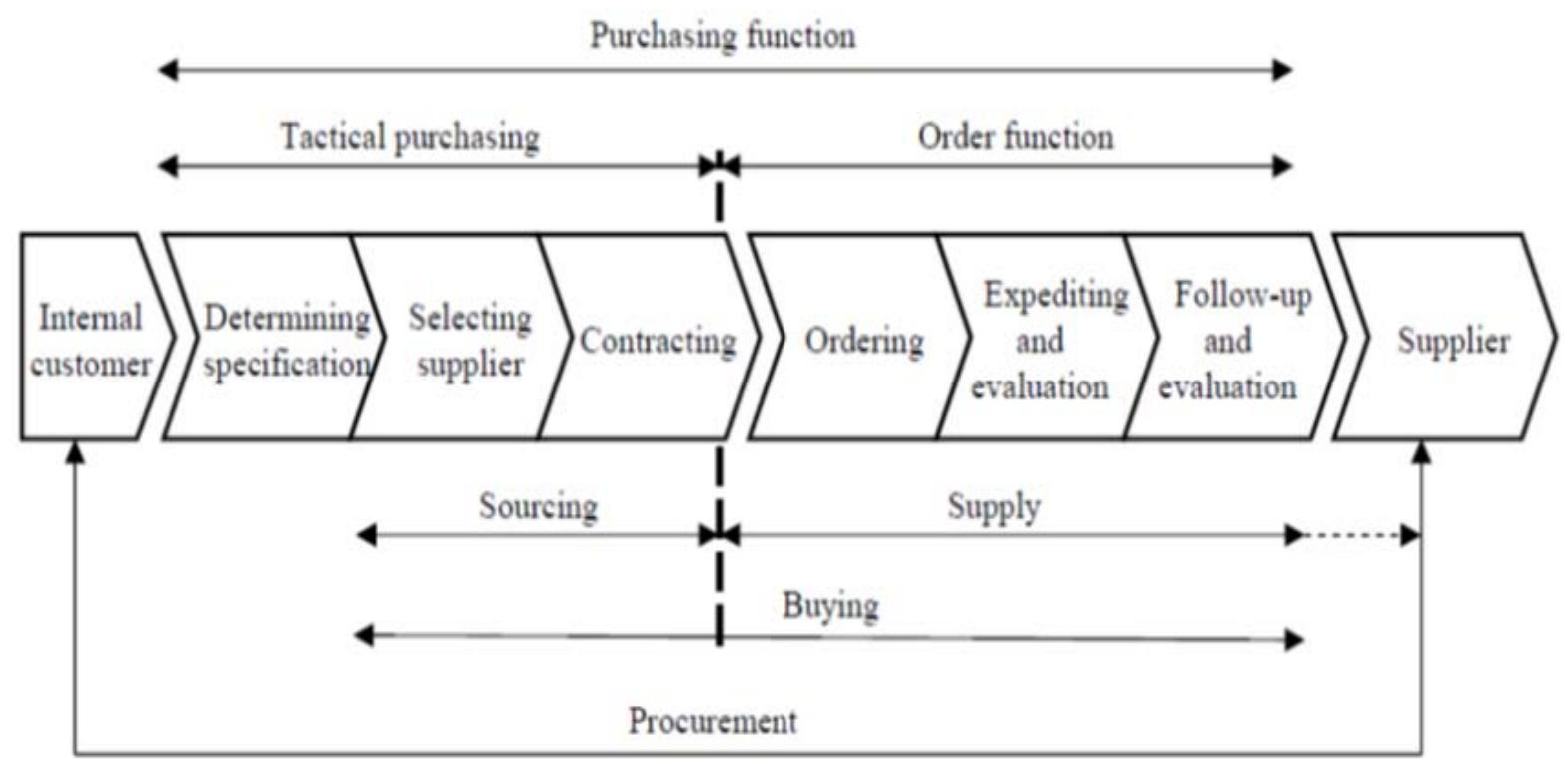

Figure 1. Purchasing process model. Source:Van Weele, 2005.

Zeng (2003) summarized some studies on the sourcing process to form a five-stage sourcing process, which included investigation and tendering; evaluation, supplier selection, and development; implementation; 
performance measurement; and continuous improvement. Figure 2 lists the activities in each stage of the sourcing process.

\begin{tabular}{|c|c|c|c|c|}
\hline 1 & 2 & 3 & 4 & 5 \\
\hline $\begin{array}{l}\text { Investigation } \\
\text { and } \\
\text { Tendering }\end{array}$ & Evaluation & $\begin{array}{c}\text { Supplier } \\
\text { Selection \& } \\
\text { Development }\end{array}$ & Implementation & $\begin{array}{l}\text { Performance } \\
\text { Measurement } \\
\text { \& Continuous } \\
\text { Improvement }\end{array}$ \\
\hline $\begin{array}{l}\text {-Core activities } \\
\text { Analysis of } \\
\text {-company, } \\
\text { customer } \\
\text { \& competitor } \\
\text {-Sourcing } \\
\text { strategy }\end{array}$ & $\begin{array}{l}\text {-Selection } \\
\text { criteria } \\
\text {-Pre-screening } \\
\text { Estimate } \\
\text { economic \& } \\
\begin{array}{l}\text { operating } \\
\text { benefits }\end{array}\end{array}$ & \begin{tabular}{|l|} 
\\
-Negotiation \\
Technical \\
assessment \\
Savings \\
identification \\
Implementation \\
Imedule \\
\end{tabular} & $\begin{array}{l} \\
\\
\text { - Team, strategy } \\
\text { \& schedule } \\
\text { Agreement on } \\
\text { - supply \& } \\
\text { Logistic terms } \\
\text { Measurement } \\
\text { of actual } \\
\text { performance } \\
\text { - Progress report }\end{array}$ & $\begin{array}{l}\text { Monitor supplier's } \\
\text { performance } \\
\text { - Relationship } \\
\text { analysis } \\
\text { Continuous Improvement } \\
\text { opportunities } \\
\text { Maintain dynamic } \\
\text { \& flexible } \\
\text { procurement } \\
\text { process }\end{array}$ \\
\hline
\end{tabular}

Figure 2. A generalized five-stage sourcing process. Source: Zeng, 2003.

Trowbridge (2006) identified eight optimal stages of the sourcing process, which include preparing for strategic sourcing, profiling the category, developing a category sourcing strategy, generating a supplier portfolio, developing competitive selection or supplier, selecting competitive suppliers and negotiating, implementing, and continuously improving. Trowbridge (2006) listed a set of activities in each stage believed to create a solid sourcing process. Table 1 lists the activities in each stage.

Table 1

The Stages and Activities of the Sourcing Process (Trowbridge, 2006)

\begin{tabular}{|c|c|c|}
\hline Stages & \multicolumn{2}{|c|}{ Activities } \\
\hline $\begin{array}{l}\text { Preparing for strategic } \\
\text { sourcing }\end{array}$ & $\begin{array}{l}\text { Do we have a sourcing project? } \\
\text { Selling early procurement involvement } \\
\text { Internal customer needs-a comparison of needs } \\
\text { Internal customer relationship management } \\
\text { Common procurement myths }\end{array}$ & $\begin{array}{l}\text { Developing a marketing plan } \\
\text { Internal customer marketing support tools } \\
\text { Establish steering committee and sponsor team } \\
\text { Establish cross-functional team } \\
\text { Project plan preparation }\end{array}$ \\
\hline Profiling the category & $\begin{array}{l}\text { Getting started with the strategic sourcing process } \\
\text { Defining the sourcing category } \\
\text { Identify basic category characteristics } \\
\text { Collect and analyze basic information } \\
\text { Expenditure analysis } \\
\text { Request for information (RFI) } \\
\text { Stakeholder interviews }\end{array}$ & $\begin{array}{l}\text { Process review and mapping } \\
\text { Total cost of ownership identification } \\
\text { Cost reduction/opportunity development } \\
\text { Market analysis } \\
\text { Market segmentation identification } \\
\text { Defining balance of power in the supply market } \\
\text { Sourcing category evolution }\end{array}$ \\
\hline $\begin{array}{l}\text { Developing category } \\
\text { sourcing strategy }\end{array}$ & $\begin{array}{l}\text { Definition of sourcing strategy } \\
\text { Category positioning matrix } \\
\text { Factors determining buyer power and category } \\
\text { criticality }\end{array}$ & $\begin{array}{l}\text { Opportunities for creating value from strategic } \\
\text { sourcing } \\
\text { Strategic sourcing approach } \\
\text { Positioning the sourcing category }\end{array}$ \\
\hline
\end{tabular}


(Table 1 continued)

\begin{tabular}{|c|c|c|}
\hline Stages & \multicolumn{2}{|c|}{ Activities } \\
\hline $\begin{array}{l}\text { Generating supplier } \\
\text { portfolio }\end{array}$ & \begin{tabular}{|l|} 
Supplier portfolio generation \\
Developing the candidate supplier list \\
Supplier types \\
Supplier capabilities \\
Source location \\
Supplier profile \\
Identification of potential suppliers
\end{tabular} & $\begin{array}{l}\text { Developing the short list of prequalified suppliers } \\
\text { Evaluation criteria and methods } \\
\text { Data collection } \\
\text { Request for information } \\
\text { Supplier evaluation summary } \\
\text { Stakeholder "buy-in" }\end{array}$ \\
\hline $\begin{array}{l}\text { Competitive selection } \\
\text { or supplier } \\
\text { development }\end{array}$ & $\begin{array}{l}\text { Selection of implementation path } \\
\text { Identification of preferred supplier(s) } \\
\text { Supplier development and the strategic sourcing } \\
\text { process }\end{array}$ & $\begin{array}{l}\text { Supplier development constraints } \\
\text { Negotiation strategy—competitive vs. } \\
\text { collaborative }\end{array}$ \\
\hline $\begin{array}{l}\text { Selecting competitive } \\
\text { supplier(s) and } \\
\text { negotiation }\end{array}$ & $\begin{array}{l}\text { Preliminary strategy formulation } \\
\text { Proposal generation } \\
\text { Developing the request-for-proposal (RFP) } \\
\text { Proposal solicitation and evaluation } \\
\text { Potential post-bid problems } \\
\text { Post-bid strategies }\end{array}$ & \begin{tabular}{|l|} 
Negotiations overview \\
Negotiation goals \\
Negotiation strategies and methods \\
Preparing for negotiations \\
Negotiation tools \\
Negotiation process
\end{tabular} \\
\hline Implementation & $\begin{array}{l}\text { Key implementation activities } \\
\text { Key implementation factors } \\
\text { Cross functional team roles and responsibilities } \\
\text { Communication needs } \\
\text { Communication methods } \\
\text { New process implementation }\end{array}$ & $\begin{array}{l}\text { Cost savings calculation and tracking } \\
\text { Savings spend baselines } \\
\text { Cost savings tracking key elements } \\
\text { Savings calculation methodologies } \\
\text { Using the market basket approach } \\
\text { Baseline savings reporting approaches } \\
\end{array}$ \\
\hline $\begin{array}{l}\text { Continuous } \\
\text { improvement }\end{array}$ & $\begin{array}{l}\text { Continuous improvement activities } \\
\text { Continuous improvement monitoring } \\
\text { Key contract administration players } \\
\text { Tips for pro-active contracting } \\
\text { Monitor performance-benchmarks }\end{array}$ & $\begin{array}{l}\text { Progression in supplier relationships } \\
\text { Supplier performance rating system } \\
\text { Supplier performance criteria } \\
\text { Supplier performance reporting } \\
\text { Benchmarking }\end{array}$ \\
\hline
\end{tabular}

A review of the literature shows that the studies classify the stages in the sourcing process (e.g., Quintens et al., 2006; Zeng, 2003; Van Weele, 2005) and identify the activities in each stage (e.g., Trowbridge, 2006). The major stages of the sourcing process include supplier selection, purchasing implementation, performance of supplier measurement, and further development. Trowbridge (2006) provided a detailed checklist of the sourcing process at the practical level. The stage Trowbridge (2006) identified comprises more preparation activities at the strategic level and an in-depth analysis of internal sourcing management.

\section{Research Design}

\section{Research Methodology}

The paper proposes a "how" question to study the supply chain management of Finnish companies when using Chinese suppliers. The research intends to reveal descriptive and exploratory information to understand the practices and process of the supply chain. The research purpose led to a qualitative method first to better understand the phenomenon remaining unknown; second, to gain new perspectives on matters already well known; and third, to gain more in-depth information that may be difficult to convey with quantitative means (Strauss \& Corbin, 1998).

A case study is a typical qualitative method for conducting "how" or "why" questions, especially when the investigator has little control over the events or when the boundaries between the studied phenomenon and real-life context are not clear-cut (Yin, 1994). In the study, a multiple-case approach is used. The purpose for using multiple cases is to produce analytical generations of the findings (Yin, 1994). 


\section{Case Companies}

There are five case companies from Finland in the study. Four are located in the Vaasa region and one in Vantaa. The case companies were contacted by two authors of the paper. The case companies in the Vaasa region were selected only on the condition that the case company conducts sourcing activities from China without owning a subsidiary in China. The case company in Vantaa was from a project studying the internationalization process of a Finnish company to China. The case study found that the company conducts sourcing activities mainly from Chinese suppliers. A representative office was established in China after 17 years of sourcing from China. The company has about 20 years of experience sourcing from China. The four case companies in Vaasa are SMEs (small and medium enterprises). The one in Vantaa is a group company. All the case companies are in the manufacturing industry (see Table 2).

Table 2

Case Companies and Interviewees

\begin{tabular}{llll}
\hline Case company & Business area & Sourcing items & Interviewee \\
\hline Case A & Sports clothes & All tailor-made clothes & One of the owners \\
Case B & Plastic components & Moulding production & Project manager \\
Case C & Product development service & Semi products, cables, parts and connectors & The owner of the firm \\
Case D & A grimotor cabin & Metals, glasses, tire products, coupling & Purchasing manager \\
& & gears, steering wheels, lights, etc. & \\
Case E & Machine building & Tailored products and standard products & Managing director \\
\hline
\end{tabular}

\section{Data Collection}

The data were collected through interviews with the management personnel or the owner of the case companies. Table 2 lists relevant information about the case companies and the interviewees. The names of the case companies and the interviewees are not disclosed in the paper.

Two questionnaires were used in the data collection. One questionnaire was used for the four case companies in the Vaasa region. The other questionnaire was used for the case company in Vantaa, because the researchers had focused on different project tasks when conducting the interviews. Despite the different means, the paper used the five cases as they arrived at the same end to reveal the practices of the sourcing process with the Chinese suppliers. All the interviews were conducted on the companies’ premises in 2010.

\section{Data Analysis}

The paper is part of a project and a combination of a master's thesis work and the project work. The four case companies in the Vaasa region were analyzed through a theoretical framework in the master's thesis developed by one of the authors. The master's thesis is regarded as a report of case study as it provided detailed descriptions of the case companies and their practices sourcing from China. The analysis of the case company in Vantaa was following the same analysis framework of the other four case companies in order to keep construct validity by establishing the chain of evidence and having key information from the interview transcription (Yin, 1994). This paper focuses on the case companies' sourcing practices. The theoretical part of the paper is developed based on the specified topic.

\section{Empirical Study}

\section{Case A}

Case A is a Finnish company specializing in clothes especially adapted to fit customers' training and 
competing needs. The company works closely with different athletes and sports clubs to make custom-made training and racing clothes. The company makes designs according to customer needs. The company purchases all sporting clothes designed for its customers. So far, it has five suppliers in China.

Originally, the company purchased sporting clothes from Estonia in 1999. The price level started to increase very quickly after Estonia became a member of the EU (European Union). The company switched suppliers from Estonia to China because of the low labor costs, material costs, and Chinese expertise in the garment industry.

One owner of the company had a friend working in China. Choosing the supplier was quite easy because the friend in China was familiar with the culture and had connections to Chinese suppliers in the garment industry. The company started collaborating with a Chinese supplier in 2004. According to the company, it is good to have local partners because they usually know how to do business with Chinese. The best way to find a trustworthy supplier is by creating contacts with Chinese. In Chinese culture, relationships are highly respected. Local people may know someone, and that person knows someone who might be an important person in finding a decent supplier. Local people may have very strong ties with centrally placed actors in that specific industry. Another good way to find a supplier is to go through different fairs and, for instance, a local website (www.alibaba.com), where all the suppliers are listed.

Although cooperating with Chinese suppliers has been successful, there are still many complexities and problems. Chinese are not as assertive compared to Westerners, especially Finnish, and they do not always keep their promises. The company takes care of quality control itself. The company has one employee in China who visits the factory once a week. He makes sure that the clothes have the right quality. The finished clothes do not leave the factory without passing quality control.

Delivery reliability is a constant problem. Deliveries are usually late, and then the company and the supplier have to decide who will pay the costs due to delays. Clothes delivered to sports clubs go first to Helsinki and then to customers. These clothes do not go through the company. Clothes delivered to retailers go first to the company's warehouse and then to customers after passing quality control. The company takes care of research and development. The company does not collaborate with suppliers in that area.

The company has two market segments: sports clubs and retailers. Sports clubs' orders are usually easier to handle, and the order is sent to the supplier via e-mail. The delivery time is approximately two months. More complexities are included in the retailers' orders. Retailers are usually sports stores, and they want to sell their own inventory first before they are willing to order more. This causes problems for the company because it should have retailers' orders as early as possible. The order should come at least nine months before delivery, but usually the company receives orders six months before the desired delivery time. Therefore, finishing the orders on time is quite complex.

The company found several things that could improve the supply chain with Chinese suppliers. Automation is one of these. The company hopes it could control the manufacturing process in the future. Automation would clarify how the process is going and when the delivery is going to be late. Currently, it is not possible, and usually, the company is informed of late deliveries too late. Information goes via e-mail, and the company does not have access to suppliers' databases. Maintaining good relationships with suppliers takes a lot of time and effort but is worth it. The company is planning to build its own factory and own brand store, but these are only in the planning phase. 


\section{Case B}

Case B is a manufacturer offering injection and reaction injection-moulded plastic parts from single products to part assemblies. The company purchases moulds ready for production from China. They also purchase different raw materials and so on, but mostly the focus is on moulds.

The cooperation with Chinese suppliers started because of the growing competition. The company needed to be cost effective as well when competitors were purchasing cheaper from China. At the same time, the volumes started to grow; outsourcing has been very effective for handling the situation so that the company has been able to concentrate on service, product changes, and product development.

Originally, the company purchased from other countries, but nowadays all purchasing is focused on China. The company's motivation for purchasing from China was based on costs, the lack of suppliers in other countries, delivery reliability, precise culture, significant Chinese work effort, and knowledge of technology. The company participated in industry fairs in China. It also searched for suitable suppliers on the Internet, and thus found the most qualified suppliers. Nowadays the company has wide connections in China but only a couple of key suppliers, mostly in Shenzhen.

The company has only positive experiences with Chinese suppliers. It has long-term relationships with suppliers, and the cooperation is working smoothly. The company believes that it is important to visit China and see suppliers face-to-face. The most important factors when doing business with Chinese companies are quality, price, and smooth cooperation. According to the company, working with Chinese is smooth, flexible, and organized. Chinese suppliers also take care of coordinating documentation, and that is very effective and well organized. That is especially useful when something needs to be checked. The number of suppliers has grown, but the company still has, more or less, cooperation with all its suppliers.

Even though the company has key suppliers, it makes sporadic purchases from other suppliers to keep the cooperation alive. The purchasing process starts with the customer's order. First, the company discusses with the customer and finds out the customer's needs. This interaction needs to happen before purchasing activities from China can start. Delivery times are usually more than five weeks, but with the most complex parts, the delivery time can be eight to nine weeks. The company has not had any problems with delivery times, and the deliveries arrive when they are supposed to. The company receives weekly reports from its suppliers about the progress of the manufacturing process, and usually the company knows when the delivery is going to happen. The business is conducted in English. Information sharing is handled via e-mail or Skype. That is the easiest and cheapest way to communicate. It is also easier for Chinese to use e-mail, because their written English is much better than their spoken. Every key supplier has its own contact person who speaks English and Mandarin, and who can translate all the needed information. That person also acts as a link to the technical personnel.

The company takes care of logistics, and uses sea transport and air transport. The transportation method is chosen according to the weight and size of the delivery. The bigger parts are shipped, because it is much cheaper than flying. Logistic decisions are made case-by-case. The transportation costs vary according to who arranges the transportation. Usually it is cheaper when the booker is Chinese. They do not use couriers, but they arrange straight from the shipping company. This means the supplier also has to take care of taxes and customs. Chinese suppliers deliver the products to the harbor, but then the responsibility transfers to the case company. The company and its suppliers have no access to each other's databases, and the impulse for purchasing comes from customers' orders. The company also collaborates with Chinese suppliers in R\&D. The case company 
sends raw materials to China for testing. After testing, the Chinese suppliers send the test parts back to Finland with testing reports. In Finland, the moulds are tested again before being implemented and transferred to production.

The case company has specified the quality strategies for all its suppliers and how they should work to fulfill the quality requirements. Suppliers send different kinds of quality documents to the company when needed. The case company takes care of quality control when the products arrive in Finland. For the ready products, the case company performs different quality measurements, for example, hardness measurements. The case company is very satisfied with its cooperation with Chinese suppliers. The company does not have any specific development areas in mind; one suggestion would be recruiting its own employees in China, but that is only a development proposal.

\section{Case C}

Case company C offers product development services primarily for companies that design and manufacture electrical equipment. Additionally, the company produces and sells its own ergonomic and energy-efficient products. The company purchases different kinds of semi-products, cables, parts, and connectors. The purchasing part of net sales is approximately 3,000 Euros, and China's part of this is 500 Euros. Western suppliers are not as qualified; thus, the company started to find suppliers in Chinese markets. The company researched suppliers on the Internet and contacted the companies that would be the most qualified. Contact occurs via e-mail. Because the number of orders is not very significant, the company feels no need to visit China. E-mail is the best way to communicate with Chinese, and they are very active in that field. The case company now has only one supplier and uses couriers for logistics. The couriers take care of taxes and customs and transport the products from door to door.

The case company is now developing and producing its own products and has many ideas for the future. The company has now purchased USB cables from China, and production is going to start in Finland. The company has a stockpile because it is easier to purchase larger batches at the same time. According to the company, it is very important to visit China and see the supplier face-to-face. Now when there has only been one order from this supplier, it is not yet necessary to go and visit in China, but if the cooperation continues it would be the next step in developing cooperation. The company just trusts that the supplier can handle its work. Quality control takes place in Finland when the components have arrived. The company does not have an employee in China who could take care of quality control. The company has just a buyer-supplier relationship with its supplier, and they are not doing more collaboration.

The biggest problem in collaborating with Chinese suppliers is communication. Chinese do not speak English very well, and they are not willing to take advice from others. Quality, price, and work ethic are still the biggest reasons for choosing Chinese suppliers. Chinese are also very friendly, and it is nice to collaborate with them. The case company has not had any problems with delivery times with its supplier.

\section{Case D}

Case company D is a manufacturer producing cabins for tractors. The company purchases metals, glasses, tire products, coupling gears, steering wheels, lights, etc., from China. Approximately 50 percent of the purchases come from abroad, and of this amount, 17 percent comes from China. The company first started purchasing from China in 2004 through a European company that had relationships with Chinese suppliers. The case company found its own suppliers by visiting fairs, and by using different contacts. Usually someone 
knows someone who could be a qualified supplier. Chinese business people have many contacts, so it is easier to search suppliers with the help of local people.

Price has been the main reason for purchasing from China. However, the company has not chosen the cheapest suppliers because it also requires quality. The company is cooperating with every supplier. Changing suppliers usually takes from one to two years. It takes time and energy to develop long-term and trustworthy relationships with new suppliers. This is the reason why the case company choose their suppliers very carefully in the first place. The company really wants to have a long-term and close relationship with every supplier.

In general, the case company has not had any problems with its suppliers. The only problem was with one supplier that had financial problems that led to its bankruptcy. In transportation, the case company uses DDU (delivered duty unpaid) Hampurg and DDU Mäntyluoto. This means that the Chinese supplier pays all the costs until the product is delivered to the destination. The case company pays all the destination country's taxes and customs fees. When the products are delivered, the company has a purchase inspection. If there are defects in the product, the next incoming delivery will go through different measurements.

The case company has four suppliers and three material controllers. They have a production management system producing different kinds of purchasing proposals. However, purchase orders are not transferred automatically to the suppliers' database, the orders are created manually. The company creates the orders, and the Chinese suppliers do not have access to the production management database. Cooperation with Chinese is different only because of the long distance. The process is the same as with Finnish or European suppliers. The company just sends orders little earlier to China than with European suppliers. The company has a two-week stockpile of products ordered from European countries and a one-month stockpile of Chinese products.

Communication happens mainly via e-mail. The purchasing manager of the company travels regularly to China and spends two weeks there. The company also collaborates in R\&D with its suppliers. It gives specific requirements for products and defines customers' requirements. The Chinese suppliers design products according to these guidelines and produce the final products for the case company. The planning is done in Finland and the designing in China. In the future, the goal is to have closer relationships with suppliers. Finnish and especially Chinese respect long-term relationships. The case company would like to have more cooperation in $R \& D$ and is going to put a lot of effort into that.

The case company has not had any problems, and the supply chain between Finland and China works the same way as with Finnish suppliers. The case company has been very satisfied with its suppliers. The suppliers were chosen very carefully, and the vendors' expertise is excellent. The Chinese work ethic is very high, which has affected the level of satisfaction. Chinese are also very committed and accurate. They respect their customers and are willing to do more for satisfied customers. For Chinese, the most important issues are customer satisfaction and adding value. The case company would prefer to choose all their suppliers from Asia, if the distances were shorter. The case company has been very satisfied with the smooth supply chain, and does not see any reason for changing anything crucial. One thing to approve would be the storage, because it is causing significant costs. The case company expects that suppliers should take care of warehousing more, and in that way, they could share the costs of warehousing more effectively.

\section{Case E}

Case company $\mathrm{E}$ is a group company providing individual components, semi-finished products, assemblies, and demanding equipment in the machine building industry. The company has been sourcing 
components from China for about 20 years.

The company is searching for potential suppliers from China. It has gone through around 500 throughout China. The company seeks Chinese through many ways such as fairs, the Internet, customers, and Finnish intermediaries. The starting point is through its Chinese personnel and their friendship networks. The company used "word of mouth" to find trustworthy suppliers. Quality and price are absolutely the two important factors when seeking suppliers. The company pays attention to suppliers' quality standards to evaluate a supplier's reasonable quality level. Especially, the company would learn and evaluate the quality in the future based on the quality standard.

The company audited potential suppliers and ordered test series and model series. The company is negotiating with Finnish customers about the types of products being sourced from China and customer needs. Then the case company takes care of sourcing and the quality of the items.

The company believes that there are no communication problems as the company has many Chinese and Chinese-speaking personnel. However, the company also has found persons capable of speaking English during the sourcing process.

The case company highlights some differences from their intensive sourcing activities in China. First, the challenges have been related to understanding the specifications as Chinese technical standards are so different. It causes problems for the company when it explains these specifications to Finnish customers. When the company is unable to test the quality of materials internally, the company uses an intermediary organization such as VTT (Technical Research Centre of Finland) to conduct the test. The second problem is related to payment processes. The company is usually asked to pay in advance so that the Chinese suppliers are able to buy raw materials and produce the product. Third, the company has observed that there are differences in understanding the importance of quality. The case company states that when test products are ordered from Europe, the company considers how the final product can be produced at the supplier's top level. In some cases, Chinese suppliers take the test products as a kind of the draft of the desired product. The case company just thought that this supplier was not capable of producing what the company wanted as the test products were poor quality. However, later on when the supplier found out that the company really wanted to order those products, the supplier was fully capable of producing what the company wanted. On the other hand, in some cases the first products received were exactly as the quality requirements, but then the Chinese supplier started thinking a different kind of quality was also acceptable. Thus, the supplier would use another type of steel when specified materials were not available. Shortcuts were taken, and then the products did not last long in Finland's cold environment. The case company believes that some Chinese suppliers do not understand the importance of sustainable, continuous quality as the quality culture is not well developed. Although the quality level is quickly progressing in China, the company still finds opportunistic suppliers that want to make extra money in the short term by taking shortcuts. This is why the case company audits quality assurance on-site in China. The company always audit the way Chinese companies function beforehand. If the quality is evaluated as sufficient, the company continues to follow the level of price development closely.

The case company expects improvements in sourcing from China should be focused on on-time delivery and continuous quality.

\section{Cross-case Discussion}

The case study illustrates the practices of Finnish companies in sourcing from China. The main tools for 
finding potential suppliers are the Internet, personal contacts, and trade fairs. The case companies used the Internet to find information about suppliers. Google is a good way to find information and the website (www.alibaba.com) where all the suppliers are listed. Visiting Chinese fairs is a good way to find contacts and qualified suppliers. It is good to have local contacts because usually they have even more contacts. Chinese respect meeting face-to-face so it is also important, every now and then, to visit China. Developing personal trust is very important in China. Guanxi, meaning "personal relations”, is highly emphasized in China. Deep trust is also important for successful business relations in China. Regular visits to the country help create a friendly and cooperative atmosphere, which in turn facilitating exchanging information, building mutual trust, and managing quality control and other supervisory activities efficiently. The tighter the links to Chinese partners, the more explicitly relations can be managed.

The orders are sent via e-mail. Because of the long distance, companies usually prepare for longer delivery times; that is why they send Chinese orders earlier than European orders. E-mail is the easiest way to communicate with suppliers. Chinese usually write English better than they speak it. Chinese suppliers send different reports and documents in different manufacturing phases, and companies usually know when the suppliers are going to deliver the products. All the companies send orders manually, and suppliers do not access the companies' databases. Orders do not automatically go to suppliers. Logistics is usually handled through couriers or by the suppliers. The suppliers usually pay the costs until the product has been delivered to its destination. The buyer pays the destination country's customs and taxes. Delivery times have been accurate in three interviewed companies; only one company has had problems with delivery times.

Quality is the central issue when sourcing from China. Purchase inspection happens in Finland and in China. Some companies work closely to audit the quality of products on-site in China before the suppliers deliver the products to Finland. Other companies conduct quality control when the products are delivered to Finland. After the inspection, the products are delivered to the customers or they are moved to the production line. If a problem occurs, the supplier is informed, and compensation will be made. Only a few reclamations have been made, because Chinese products are good quality and are properly made.

Two of the five case companies are cooperating with suppliers in $R \& D$ at the current stage. In the future, the two companies expect to develop the R\&D collaboration further. The other companies may develop collaborate with suppliers and expand to R\&D. Chinese expertise is so high that companies are outsourcing their designs to Chinese suppliers.

The main reasons for choosing Chinese suppliers are price, quality, expertise, and high work ethic and perseverance. Due to the increasing competition globally, companies must become more cost-effective. Even though the logistics distances are long, purchasing from China is still cheaper than from Europe. China also offers a large scale of suppliers compared with European countries. Price is tempting, but usually companies do not choose the cheapest supplier. Quality and price make a strong combination that affects the choice of supplier. Good cooperation also affects satisfaction and continuity of collaboration.

In general, the case companies have been very satisfied with their cooperation with Chinese suppliers and with the smoothness of the supply chain. Chinese were described as faithful, friendly, precise, efficient, competent, and organized, and they really respect their customers. In addition to communication problems because of the language barrier, the case companies illustrate the central problems of on-time delivery and sustainable quality control, especially differences in understanding quality (e.g., case E).

The case study illustrates the practices of Finnish companies in the sourcing process from China. Figure 3 
summarizes the stages and activities of the sourcing process.

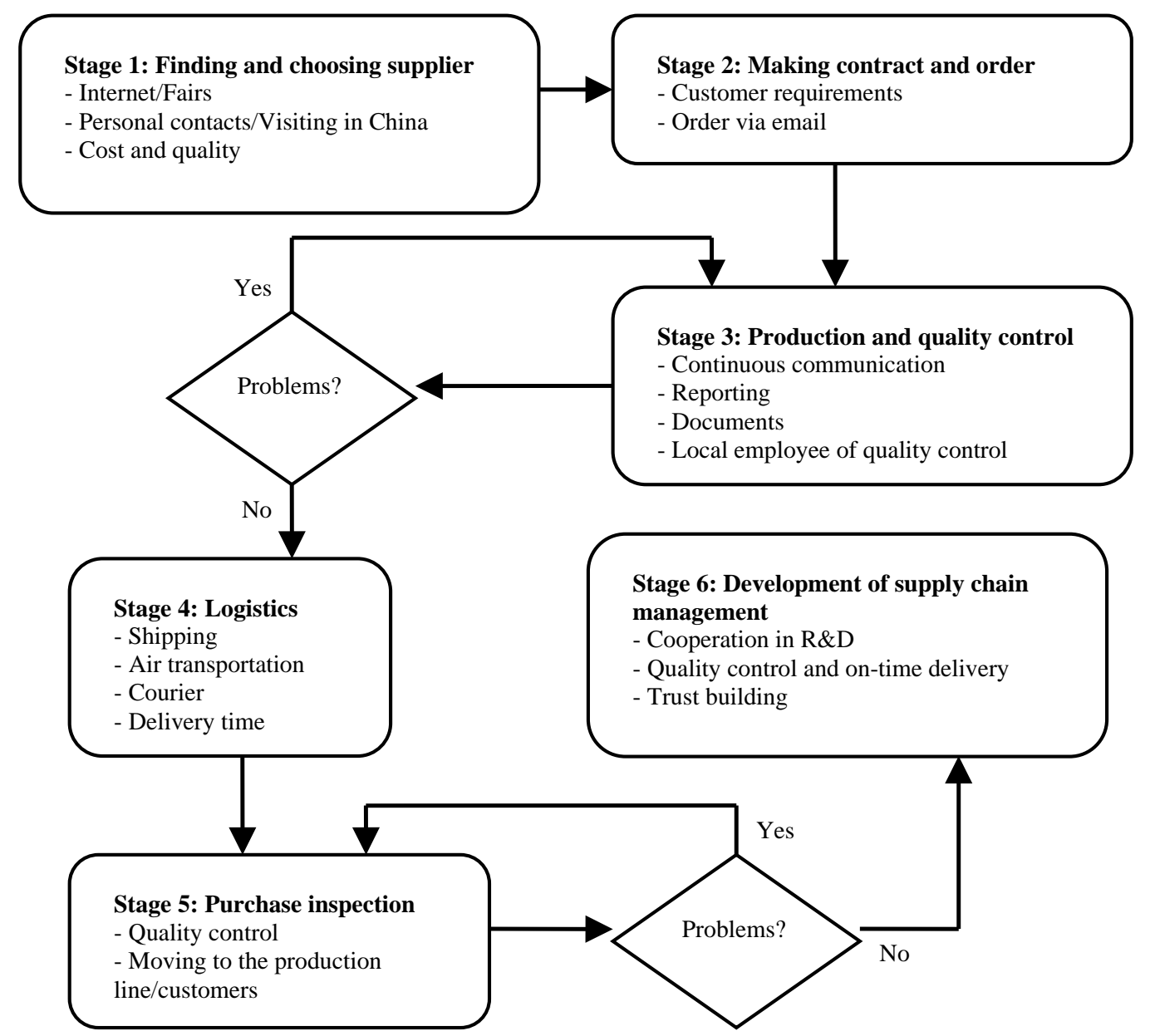

Figure 3. Sourcing process of Finnish companies in China.

\section{Conclusions}

The paper studies the sourcing process of supply chain management through learning the practices of Finnish companies sourcing from China. There are six stages of sourcing from China in the cases: finding and choosing suppliers, making contracts and orders, production and quality control, logistics, purchasing inspection, and developing supply chain management. The Finnish case companies seek potential suppliers through the Internet, trade fairs, networking, and local visits. Cost and quality are the two main factors when selecting a qualified supplier. Communication with Chinese suppliers is conducted mainly through e-mail to exchange quality specifications and information about the orders. Quality control is the central issue in the sourcing process. The Finnish companies attempt many ways to guarantee quality by checking the Chinese suppliers' quality standards, asking for production reports and documentation, and using a local employee for quality control. The problem in logistics is on-time delivery, although some companies have not suffered the problem of delayed delivery. The case companies double-check when the products arrive in Finland. The experiences of the case companies with Chinese suppliers are positive. The case companies and Chinese suppliers expect to establish long-term cooperative relationships in R\&D, quality control, and on-time delivery. 
A framework of the sourcing process was developed in the paper (see Figure 3).

Theoretically, the case study does not illustrate that sourcing from China is quite different from sourcing from other countries (e.g., Zeng, 2003; Van Weele, 2005). The major stages of the sourcing process are similar. Compared with Trowbridge's (2006) study, the case study also does not reveal many activities on the preparation stage. One explanation is the case companies already identified China as the sourcing destination. The other explanation is the organizational structure is simple as most of the case companies are SMEs. However, the case study highlights the core activity of sourcing from China is quality control. One more phase focuses on quality control in the process of sourcing from China. Especially in case E, the company emphasizes there are differences in the understanding of sustainable quality between the Finnish company and the Chinese supplier. The difference can affect supplier screening and quality control. The study generates managerial implications that sourcing from China is more or less a continuous process of quality supervision and improvement. In this sense, it is important that a long-term relationship with a trustworthy supplier is built in the process of sourcing from China so that the companies can achieve cost advantage.

There are some methodology limitations in the research. First, all the case companies involved in the study show very satisfactory sourcing experiences with Chinese suppliers. From the methodology perspective, the five companies are successful cases. The failure cases are not available in the process of selecting case companies as they do not have any business relationships with Chinese suppliers. Therefore, the sourcing practices may not exhaustedly reveal all challenges in other situations. Second, the findings of the study mainly focus on the sourcing practices when the companies do not have their own physical facilities in China. The research results may not be directly applied to the sourcing process of those companies with local production premises in China. For further study, it is worth exploring a detailed study on quality control with Chinese suppliers. Furthermore, the research is supposed to significantly improve the practices of sourcing from China when companies expect to achieve cost competitiveness.

\section{References}

Campbell, R. M., Hexter, J., \& Yin, K. (2004). Getting sourcing right in China-Three issues hold the key to working successfully with Chinese suppliers. The McKinsey Quarterly, Special Edition. China today.

Cooper, M. C., Lambert, D. M., \& Pagh, J. D. (1997). Supply chain management: More than a new name for logistics. The International Journal of Logistics Management, 8(1), 1-14.

Enderwick, P. (2009). Avoiding quality fade in Chinese global supply chains-Designing appropriate governance structures. Business Process Management Journal, 15(6), 876-894.

Fredriksson, A., \& Jonsson, P. (2009). Assessing consequences of low-cost sourcing in China. International Journal of Physical Distribution \& Logistics Management, 39(3), 227-249.

Gelderman, C. J., \& Semeijn, J. (2006). Managing the global supply base through purchasing portfolio management. Journal of Purchasing \& Supply Management, 12, 209-217.

Karpak, B., Kumcu, E., \& Kasuganti, R. R. (2001). Purchasing materials in the supply chain: Managing a multi-objective task. European Journal of Purchasing \& Supply Management, 7, 209-216.

Meixell, M. J., \& Gargeya, V. B. (2005). Global supply chain design: A literature review and critique. Transportation Research Part, 41, 531-550.

Mentzer, J. T. (2001). Supply chain management. Thousand Oaks, California: Sage Publications.

Min, H., \& Zhou, G. (2002). Supply chain modeling: Past, present and future. Computer \& Industrial Engineering, 43, $231-249$.

Pennanen, M., Muhos, M., Wang, L., \& Kess, P. (2011). Supply chain management between Finland and China: Empirical evidence from Vaasa region. Working paper in Department of Industrial Engineering and Management 2/2011, University of Oulu.

Pyke, D., Robb, D., \& Farley, J. (2000). Manufacturing and supply chain management in China: A survey of state-, collective-, 
and privately-owned enterprises. European Management Journal, 18(6), 577-589.

Quintens, L., Pauwels, P., \& Matthyssens, P. (2006). Global purchasing strategy: Conceptualization and measurement. Industrial Marketing Management, 35, 881-891.

Salmi, A. (2006). Organising international supplier relations: An exploratory study of Western purchasing in China. Journal of Purchasing \& Supply Management, 12, 197-208.

Strauss, A. L., \& Corbin, J. (1998). Basics of qualitative research: Grounded theory procedures and techniques (2nd ed.). Inc. Newbury Park, C.A.: Sage Publications.

Trowbridge, M. (2006, September/October). Optimal stages of strategic sourcing... what are they really? Best Practices Journal (30th ed.).

Van Weele, A. J. (2005). Purchasing and supply chain management: Analysis, strategy, planning and practice (4th ed.). Thomson Learning, London.

Yin, R. K. (1994). Case study research: Design and methods (2nd ed). Inc. California: Sage Publication.

Zeng, A. Z. (2003). Global sourcing: Process and design for efficient management. Supply Chian Management: An International Journal, 8(4), 367-379.

Zhang, L., \& Goffin, K. (2001). "Managing the transition”-Supplier management in international joint ventures in China. International Journal of Physical Distribution \& Logistics Management, 31(2), 74-95. 